\title{
CHARACTERISTICS OF BIOFILM FORMATION PROCESS IN THE BIOELECTROCHEMICAL SYSTEMS, WORKING IN BATCH-MODE OF CULTIVATION
}

\author{
Liudmyla Zubchenko ${ }^{1, *}$, Yevhen Kuzminskiy ${ }^{1}$
}

DOI: dx.doi.org/10.23939/chcht11.01.105

\begin{abstract}
A short overview of the formation methods of the biofilm with high exoelectrogens activity, which includes alternate partial and complete changes of culture medium, was done in the article. The influence of adaptation processes on electric current generation during the exoelectrogens biofilm formation was analyzed. The article also describes the reasons of sharp current variation, which appeared after nutrient medium changes.
\end{abstract}

Keywords: microbial fuel cells, exoelectrogenes, anodic biofilm, wastewater treatment.

\section{Introduction}

The performance of current generation in microbial fuel cells (MFC) primarily depends on activity of the exoelectrogenic microorganisms that oxidize organic matter and transfer electrons to the anode.

A wide range of substrates, such as wastewater, activated sludge, sediment [1,2], soil [3] and others are used to isolate exoelectrogenes, because these substrates include associations of microbes, belonging to different genera. Analysis of the anode biofilms, formed using these sources of inoculum, show a wide variety of bacteria in anodophillic consortia, but they also have weak bioelectrochemical activity [1]. Firstly, it may deal with the presence of a large number of not-exoelectrogenic microorganisms in anodic biofilm. Electron generating communities may be operationally difficult and even have a wide phylogenetical diversity, but only microorganisms, that completely oxidize organic matter, can significantly influence the electricity generation process [4]. Logan and

\footnotetext{
${ }^{1}$ National Technical University "Kyiv Polytechnic Insitute"

37, Peremogy Ave., (block. 4, r. 182), 03056 Kyiv, Ukraine

l.zubchenko@kpi.ua

(C) Zubchenko L., Kuzminskiy Y., 2017
}

Regan [5] reported that anodophillic consortia in MFC can be sustainable only if the biofilm is enriched through transfer and selection.

Specific conditions, which will provide the primary growing of exoelectrogenes, should be created during the biofilm formation process to remove microorganisms, which don't have exoelectrogenical ability. Thus, the biofilm formation process is very important, and the efficiency of microbial fuel cells operation, in many cases, depends on successful realization of this process.

The biofilm formation process is often carried out through cyclic inoculum and nutrient substrate feeding to the reactor [6]. The cycle usually ends, when exoelectrogenes have metabolized all the substrates. New portion of inoculum and substrate should be added to the pre-cleaned and sterilized reactor at the end of each cycle. The process is controlled by measuring the electrical current or voltage, generated by microorganisms in MFC [7]. When MFC reach a stable value of the measured parameter (electrical current, voltage) during several consecutive cycles, the process of biofilm formation is considered to be complete. Often, the second stage of biofilm formation process is performed. Two-stage biofilm formation method includes several cyclic inoculations during the first stage, followed by the enrichment of formed biofilm, which includes substrate adding without inoculum introduction [7-9].

Sometimes, continuously flow reactors are used [10]. This mode provides a continuous supply of fresh inoculum and substrate, and constant removing of cultural solution from the reactor.

Since many exoelectrogenic microorganisms, found in MFC, are metal-reduction bacteria, a method of expressing biofilm formation was developed. This method includes the stage of cultivation on the medium, containing crystalline iron oxide [1]. The initial biofilm was grown on MFC anode and then collected from the anode of the MEC and used as the inoculum for the 
enrichment procedure. Fe(III) oxide should be provided to the growing medium as the electron acceptor.

After cultivation on the medium with $\mathrm{Fe}(\mathrm{III})$ oxide, microorganisms, which are able to iron oxidization, can be isolated and then transferred to the MFC reactor.

Among the microorganisms that are typically isolated from exoelectrogenical active biofilms, which were formed using anaerobic activated sludge, such families as Geobacteraceae, Desulfuromonaceae, Alteromonadaceae, Enterobacteriaceae, Pasteurellaceae, Clostridiaceae, Aeromonadaceae and Comamonadaceae are often encounter [12, 13]. Gammaproteobacteria, Betaproteobacteria, Rhizobiales have also the exoelectrogenical ability. Under thermophilic conditions Thermincola carboxydophila, Deferribacter ferribacter, Coprothermobacter sp. have also the mentioned properties [12].

It is important to note, that exoelectrogennical phenomenon is observed in both cases: when we use pure culture of microorganisms (monoculture) and when we use the associations of microorgnism, belonging to different genera.

According to researches $[12,14,15]$, the biofilm which consists of a mixed culture of microorganisms, generates greater current density than the biofilm, formed from pure culture, during consumption of complex substrates (for example, wastewater).

This can be explained as follows: most of exoelectrogens can consume a limited range of substrates [16]. The oxidation of wastewater requires a diverse microbial group, members of which will be able to consume all substances present in the mixture and transform them into the form, suitable for consumption by exoelectrogens. But one of the most important factors, during the work with mixed cultures is regulation of the amount of microorganisms, which don't have exoelectrogenical activity. These microorganisms can block the access of exoelectrogens to the anode and, thus, the amount of electrons that microbial cells can transfer to the anode, decreases as well as the overall performance of the system.

The aim of this work is to study the influence of alternate partial and complete changes of culture medium on the process of exoelectrogenes-rich biofilm formation on the MFC anode.

\section{Experimental}

\subsection{M aterials and Methods}

Microbial fuel cell reactor consisted of two polypropylene chambers, which were connected by salt bridge. The volume of each chamber was $1000 \mathrm{~cm}^{3}$. The anode chamber was hermetically closed by polypropylene lid. Silicone adhesive sealant (Permatex, INC., Hartford Square North,) was used for hermetic sealing. The cathode chamber was open for free access of air to the cathode. The outer circle resistance was installed $1000 \Omega$.

The salt bridge was prepared by dissolving $\mathrm{KCl}$ in hot bacterial agar solution of Typ USA type (FERAK BERLIN, Berlin, Germany, EU) with $\mathrm{KCl}$ :BA ratio of $74.53: 20 \mathrm{~g} / \mathrm{dm}^{3}$ and poured into the connection hose. The carbon cloth with $4 \times 17 \mathrm{~cm}$ dimensions and $68 \mathrm{~cm}^{2}$ surface area was used as the anode and cathode electrode. The following composition was used as a phosphate buffer solution, $\mathrm{g} / \mathrm{dm}^{3}: \mathrm{NaH}_{2} \mathrm{PO}_{4}-2.13 ; \mathrm{Na}_{2} \mathrm{HPO}_{4}-4.58$; $\mathrm{NH}_{4} \mathrm{Cl}-0.31 ; \mathrm{KCl}-0.13$. Basic solution also contained trace mineral and vitamin solutions to provide vital functions of microorganisms.

Trace mineral solution consisted of: $\mathrm{CaHPO}_{4} 2 \mathrm{H}_{2} \mathrm{O}-$ $40 \mathrm{mg} / \mathrm{dm}^{3}, \mathrm{KCl}-7.5 \mathrm{mg} / \mathrm{dm}^{3}, \mathrm{MgO}-100 \mathrm{mg} / \mathrm{dm}^{3}$, $\mathrm{C}_{12} \mathrm{H}_{24} \mathrm{FeO}_{14}-27 \mathrm{mg} / \mathrm{dm}^{3}, \mathrm{CuSO}_{4}-2 \mathrm{mg} / \mathrm{dm}^{3}, \mathrm{MnSO}_{4}-$ $5 \mathrm{mg} / \mathrm{dm}^{3}, \mathrm{KI}-150 \mu \mathrm{g} / \mathrm{dm}^{3}, \mathrm{Na}_{2} \mathrm{SeO}_{4}-10 \mu \mathrm{g} / \mathrm{dm}^{3}, \mathrm{ZnO}-$ $15 \mu \mathrm{g} / \mathrm{dm}^{3}, \mathrm{Na}_{2} \mathrm{MoO}_{4} \cdot 2 \mathrm{H}_{2} \mathrm{O}-15 \mu \mathrm{g} / \mathrm{dm}^{3}, \mathrm{CrCl}_{3} \cdot 6 \mathrm{H}_{2} \mathrm{O}-$ $15 \mu \mathrm{g} / \mathrm{dm}^{3}$.

Trace vitamin solution consisted of: retinol acetate (vitA) - $1.2 \mathrm{mg} / \mathrm{dm}^{3}$, dl- $\alpha$-tocopherolacetate (vitE) $2.3 \mathrm{mg} / \mathrm{dm}^{3}$, betacarotene (vitA) $-0.6 \mathrm{mg} / \mathrm{dm}^{3}$, thiamine mononitrate (vitB1) $-3 \mathrm{mg} / \mathrm{dm}^{3}$, calcium pantothenate (vitB15) - $10 \mathrm{mg} / \mathrm{dm}^{3}$, cyanocobalamin (vitB12) $9 \mu \mathrm{g} / \mathrm{dm}^{3}$, pyridoxine hydrochloride $-6 \mathrm{mg} / \mathrm{dm}^{3}$, folicacid-100 $\mu \mathrm{g} / \mathrm{dm}^{3}$, riboflavin (vitB2) $-3.4 \mathrm{mg} / \mathrm{dm}^{3}$, nicotinamide (vitPP) - $20 \mathrm{mg} / \mathrm{dm}^{3}$, biotin (vitH) $30 \mu \mathrm{g} / \mathrm{dm}^{3}$, ascorbic acid (vitC) $-90 \mathrm{mg} / \mathrm{dm}^{3}$, calciferol (vitD) $-0.01 \mathrm{mg} / \mathrm{dm}^{3}$, pyridoxine hydrochloride (vitB6) $3 \mathrm{mg} / \mathrm{dm}^{3}$.

The solution in the anodic chamber was purged with argon to displace dissolved oxygen from the solution before running the reactor.

Anaerobic activated sludge from water treatment station "Kyivvodocanal" was used as inoculum. MFC was operated at ambient temperature of $302 \pm 1 \mathrm{~K}$.

\subsection{Experimental Technique}

The anode chamber was filled with a phosphate buffer solution with the addition of vitamins and mineral components solutions and the sodium acetate, as a substrate. Anaerobic activated sludge was added as an inoculum. The anodic solution before starting MFC (chamber volume $1000 \mathrm{~cm}^{3}$ ) contained: phosphate buffer solution $500 \mathrm{~cm}^{3}$, vitamin solution $-7 \mathrm{~cm}^{3}$, mineral components solution $-13 \mathrm{~cm}^{3}$, anaerobic activated sludge $-480 \mathrm{~cm}^{3}$, sodium acetate trihydrate $\left(\mathrm{CH}_{3} \mathrm{COONa} \cdot 3 \mathrm{H}_{2} \mathrm{O}\right)-1.36 \mathrm{~g}$ (10 mmol).

On the third day of MFC cultivation the voltage was $130 \mathrm{mV}$ and continued to rise. On the fourth day of 
cultivation the voltage reached $200 \mathrm{mV}$, and then began to subside probably due to the decrease of the substrate in the chamber. On the ninth day of cultivation, a complete replacement of the nutrient medium with adding of new batch of inoculum was done. Compositions of anodic and cathode solution were the same, as in the case of starting. Maximum voltage was $340 \mathrm{mV}$ in the beginning (first peak) and then reached $248 \mathrm{mV}$ during the cycle.

The partial replacement of cultural medium means the replacement of $500 \mathrm{~cm}^{3}$ of anolyte for fresh phosphate buffer solution containing vitamins, minerals, sodium acetate and a new batch of inoculum. So, the solution, added on the twenty-third day of cultivation contained: phosphate buffer solution $-120 \mathrm{~cm}^{3}$, vitamin solution $7 \mathrm{~cm}^{3}$, mineral components solution $-13 \mathrm{~cm}^{3}$, anaerobic activated sludge $-350 \mathrm{~cm}^{3}$, sodium acetate trihydrate $\left(\mathrm{CH}_{3} \mathrm{COONa} \cdot 3 \mathrm{H}_{2} \mathrm{O}\right)-1.36 \mathrm{~g}(10 \mathrm{mmol})$.

The voltage increased to $230 \mathrm{mV}$ within a short time after adding fresh inoculum and nutrient substrate. On the thirty-second day of biofilm formation the voltage decreased below the initial level of this cycle, this was associated with the depletion of the substrate in the anode solution, so a complete replacement of the anodic solution was made with introducing a new portion of the substrate.

The anodic chamber was filled with phosphate buffer solution with the addition of substrate solution, vitamins, mineral components and anaerobic activated sludge as inoculum. Resistance in the outer circle was changed to $100 \Omega$.

The voltage, generated by MFC, started growing and reached $453 \mathrm{mV}$ in a half of hour, after complete replacement of nutrient medium. The voltage decreased to $217 \mathrm{mV}$ on the thirty-sixth day of the experiment, and slowly decreased to $163 \mathrm{mV}$ on the thirty-ninth day. Next partial replacement of the substrate was performed on the fortieth day of cultivation, according to previous recipe, after that the voltage increased to $240 \mathrm{mV}$ in the first peak and set at $220 \mathrm{mV}$ in the second part of the cycle.

\section{Results and Discussion}

\subsection{Electrical Activity Analysis}

According to the obtained values of voltage, the current generated in MFC was calculated. The changes of the current, as a function of the duration of biofilm formation process, are presented (Fig. 1) for electrochemically active microbial population. It follows from the graph, that the slight current generation at the initial stage of the biofilm formation indicated that microbial biofilm development was weak. Such weak microbial biofilm development actually corresponds to the initial stage. The current reached $200 \mu \mathrm{A}$ in the middle of the cycle and then began to decline. Complete change of anode solution promoted the generation of current with two peaks during the cycle. The first peak $-340 \mu \mathrm{A}-$ appeared directly after anode solution replacement and the second peak $-248 \mu \mathrm{A}$ was on the nineteenth day of cultivation.

After the partial replacement of culture medium and adding fresh inoculum, a rapid increase in current strength was observed. Then the current began to rise slowly, reaching a maximum value of $194 \mu \mathrm{A}$ and then decreased. After complete replacement of nutrient medium the current increased sharply and reached a maximum value of $453 \mu \mathrm{A}$. But after that the current rapidly decreased, with its following slow growth to a level of $217 \mu \mathrm{A}$ and subsequent decline. The next partial replacement of culture medium led to another gradual current increase to $220 \mu \mathrm{A}$.

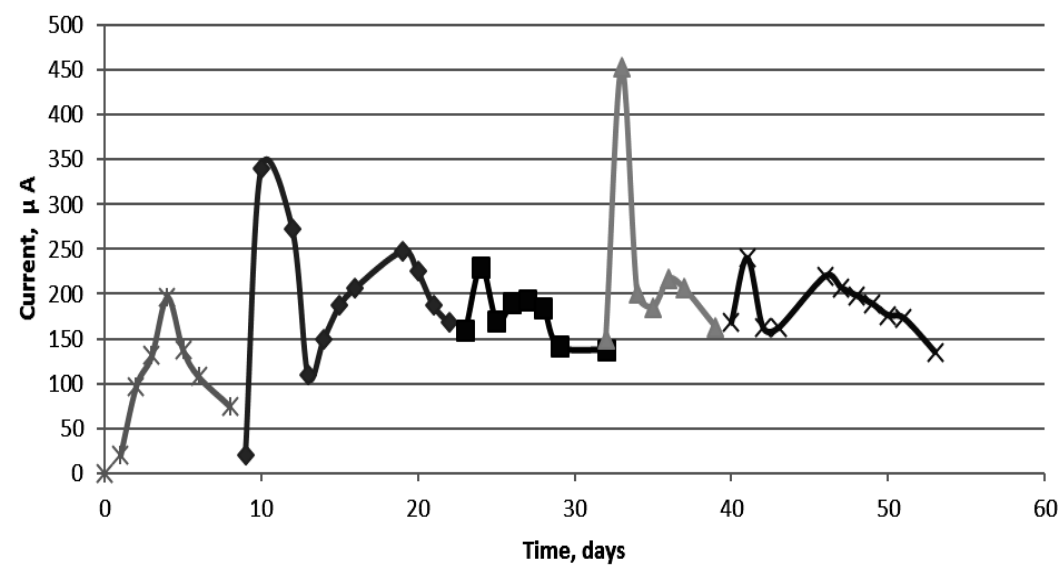

Fig. 1. Current vs. time during the biofilm formation process of electrochemically active microorganisms: - start of biofilm formation process; - - partial replacement of cultural medium $1 ;-$ complete replacement of cultural medium; $\leftarrow$ partial replacement of cultural medium 2 
We assume that a rapid current increase after replacement or partial replacement of culture medium and adding fresh portions of inoculum is associated with the following factors:

- the addition of the fresh substrate leads to the increase in the rate of metabolism in a biofilm formed on the anode;

- the addition of the fresh inoculum increases the number of exoelectrogenic microorganisms in the anodic solution;

- the manipulation with the anodic solution leads to the increase of the mass transfer intensity in the chamber.

The subsequent rapid decline of the current generation that followed the rapid increase, was probably associated with the decrease of a suspended microbial biomass number, due to sedimentation phenomena and inhibition of microorganisms, introduced with a new portion of inoculum, because of adaptation to the new conditions of existence. Actually, electrons, which are transferred to the anode by exoelectrogens immediately after MFC inoculation, are electrons derived from the metabolism of substances. These substances were consumed prior to transfer of microorganisms to the reactor, and hence, prior to the adaptation process beginning. This explains the fact that the most significant increase in the value of the current was observed after complete replacement of the solution in the anode chamber. It should be also noted, that current increase was lower after the complete replacement of nutrient medium, compared the partial replacement of the medium. It may be associated with the existence of suspended microorganisms from the previous stage of biofilm formation, which do not require adaptation, in the anode chamber, directly after the partial replacement of the medium.

The adaptation of microorganisms to the reactor conditions is quite a difficult process. Consequently, the partial replacement of the anodic solution facilitates the process of adaptation for microorganisms. Microorganisms that have been presented in the reactor for some time before the partial replacement of the anodic solution, are able to maintain the MFC voltage directly after the MFC restart that simplifies selective adaptation for exoelectrogens but not for other microorganisms.
The biofilm development on the anode during the process of exoelectrogens biofilm formation is characterized by a constant increase of the current generation. At the initial stage of biofilm formation, when we constantly add fresh inoculum, the current generation number is unstable because of exclusion significant quantity of suspended (adapted) microorganisms via complete or partial replacement of medium.

The gradual current decrease occurred at the end of each cycle, whether substrate was fully or partially replaced, may be due to the depletion of the substrate and thus reducing the load on the activated sludge, accumulation of metabolic products and the weakening process of mass transfer.

\subsection{M icroscopic Analysis of Anode Biofilm}

Microorganisms, which have exoelectrogenic ability, belong to different genera, so identification in the anodofilic consortium requires special methods (biochemical analysis, polymerase chain reaction). Microscopic analysis of anode biofilm shows the general features of the biofilm. Main characteristics of typical microorganisms, which are often found in electroactive biofilms are given in Table.

At the beginning of the experiment, significant activity of methanogenic microorganisms (we found significant gas overpressure in the chamber) was observed in the anode chamber, but after several days of cultivation activity decreased.

Microscopic analysis of biofilm sample (gram straining), scraped from the anode showed the formation of biofilm closely associated with anode fibers. Single anode fibers, covered with different thickness biofilm layer are shown on Fig. 2a, b. Gram staining of biofilm revealed the presence of large amount of gram-negative rod-shape cells and just some cells are gram-positive.

When using immersion system (magnification of 270x) we can recognize the shape of cells, which are present in the greatest quantity (Fig. 2c, d). So, gramnegative bacilli are mostly presented in the biofilm.

Main characteristics of some microorganisms-exoelectrogenes

\begin{tabular}{|l|c|c|c|}
\hline \multicolumn{1}{|c|}{ Microorganism } & Shape of cell & Sizes, $\mu \mathrm{m}$ & Gram stain \\
\hline Geobacter spp. & Rod-shape & $0.6 \times(1-2)$ & Gram-negative \\
\hline Shewanella spp. (Pseudomonas spp.) & Rod-shape & $(0.5-1.0) \times(1.5-5.0)$ & Gram-negative \\
\hline Desulfuromonas spp. & Rod-shape & $(0.4-0.7) \times(1-4)$ & Gram-negative \\
\hline Enterobacterium spp & Rod-shape & $(0.3-0.6) \times(0.8-2.0)$ & Gram-negative \\
\hline Aeromonas spp. & Rod-shape & $(3.0-8.0) \times(1.0-1.5)$ & Gram-positive \\
\hline Clostridium spp. & Rod-shape & $(1.0-1.5) \times(1.5-2.0)$ & Gram-negative \\
\hline Acinetobacter spp. & Coccobacillus or spherical-shape & &
\end{tabular}




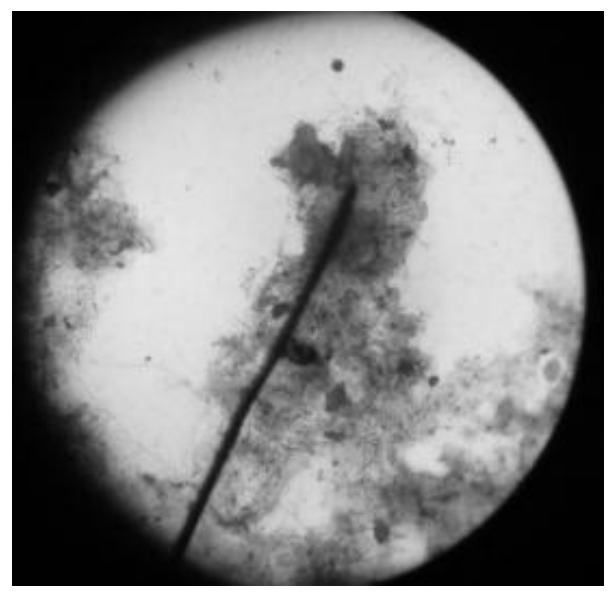

a)

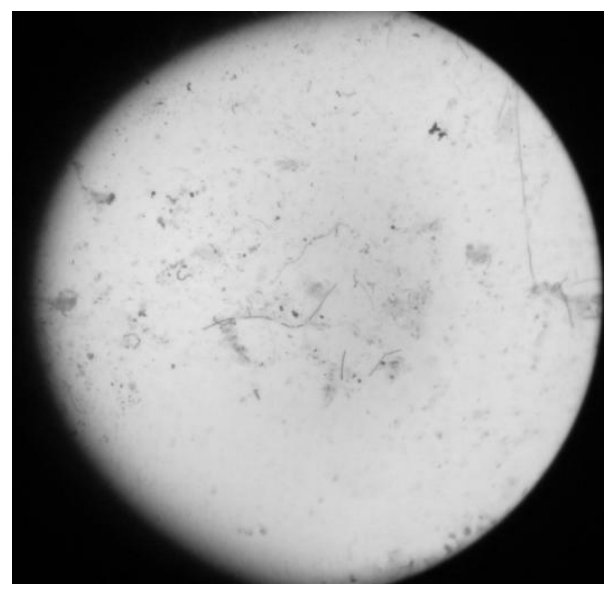

c)

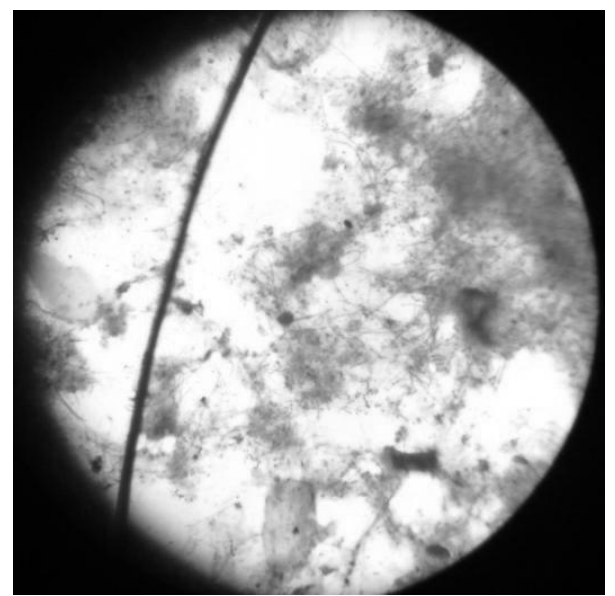

b)

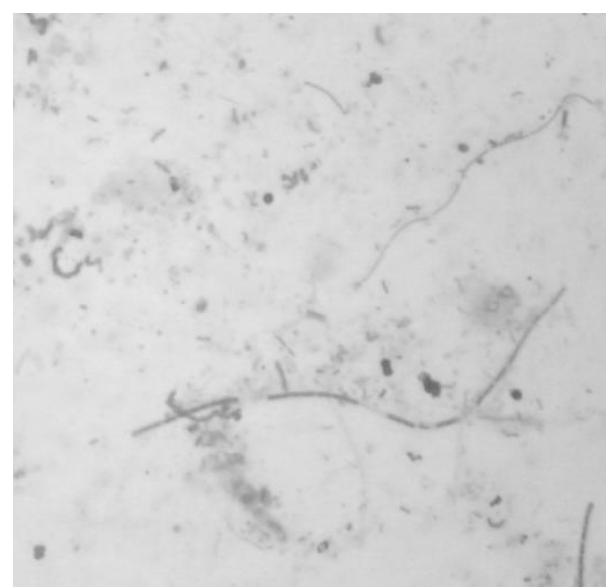

d)

Fig. 2. Microscopic micrographs of biofilm, formed on the anode of microbial fuel cell (magnification of 270x): anode fibre with flakes of biofilm (a, b); anode biofilm under immersion (c) and part of photo (c) with 3x zoom (d)

The electrical activity and gram staining of the biofilm suggest the presence of the most common electroactive microorganism (Table). Exact definition of bacterial form requires microbiological and biochemical analyses.

\section{Conclusions}

It has been observed in this study that during the process of biofilm formation the main factors that influence the biofilm development are: inoculum, the amount of added substrate, the conditions of the process.

The biofilm formation process, which includes alternately full and partial replacement of cultural medium, promotes faster biofilm development on MFC anode.

Observation of biofilm formation process suggests that fresh biomass, as that which was present in the solution before the partial replacement of culture medium, makes a significant influence on the power generating during biofilm formation process. That is why successful microbial biofilm development needs not only the presence of a high concentration of biomass and its constant renewal, but also regulation of the ratio of added biomass to the total volume of the anode chamber.

Investigation of electrochemical power generation by exoelectrogenic microorganisms confirms that the successful MFC operation requires the presence of microorganisms adapted to MFC conditions. These microorganisms have an ability to maintain the functioning of MFC, while fresh biomass is at the adaptation stage. The constant renovation of biomass is also equally important.

The main factors decelerating the biofilm formation process of microbial associations are the depletion of the substrate, the accumulation of metabolic products, reducing the concentration of active microbial biomass in the operation of the reactor.

The study of microorganisms from the anode surface and bioelectrochemical activity of formed biofilm (by measuring the voltage generated by bacteria) shows 
that the process promotes the formation of biofilm rich with exoelectrogens.

Observation of biofilm formation process, with alternate full and partial change of culture medium, suggests that fresh biomass, as well as that, which was presented in the solution, makes a significant influence on power generating during biofilm formation process. So, the process of biofilm formation with electroactive microorganisms is sensitive not only to the presence of a high biomass concentration, but also its constant renovation, and the number of value-added biomass to the total volume of the anode chamber.

\section{Referenses}

[1] Wang A., Sun D., Ren N. et. al.: Bioresource Technol., 2010, 101, 5733.

[2] Das S. and Mangvani N.: J. Sci. Ind. Res., 2010, 69, 727.

[3] van Ginkel S., Oha S. and Logan B.: Int. J. Hydrogen Energ., 2005, 30, 1535.

[4] Lovley D.: Curr. Opin. Biotech., 2008, 19, 8.

[5] Logan B. and Regan J.: Trends Microbiol., 2006, 14, 512.

[6] Ditzig J., Liu H. and Logan B.: Int. J. Hydrogen Energ., 2007, 32, 2296.

[7] Kuzminskiy Ye., Schurska K. and Samarukha I.: Bioelektrokhimichne Produkuvannia Elektrychnoi Enerhii ta Vodniu. Kyiv 2012.

[8] Schurska K., Zubchenko L. and Kuzminskiy Ye.: Naukovi visti Nats. Techn. Univ. "KPI”, 2012, 3, 88.
[9] Zielke E.: Microbial Fuel Cell Technology, https://www.engr. psu.edu/ce/enve/logan/bioenergy/pdf/Zielke_E326_Project.pdf [10] Jang J., Pham T., Chang I. et. al.: Int. J. Proc. Biochem., 2004, 39, 1007 .

[11] Semchyshyn G. and Luschak V.: Metodychni Vkazivky do Laboratornykh Zaniat z Microbioilogii. Ivano-Frankivsk 2004.

[12] Lovley D.R.: Curr. Opin. Biotech., 2006, 17, 327.

[13] Ghanggrecar M. and Shinde V.: Environ. Sci. Technol., 2008, 40, 3045 .

[14] Wang A., Sun D., Ren N. et al.: Bioresource Technol., 2010, 101, 5733 .

[15] Franks A., Malvankar N. and Nevin K.: Biofuels, 2010, 1, 589.

[16] Kiely P., Cusick R., Call D. et al.: Bioresource Technol., 2011, 102, 388 .

Received: N ovember 09, 2015 / Revised: J anuary 28, 2016 / Accepted: J une 12, 2016

\section{ПАРАМЕТРИ ПРОЩЕСУ ФОРМУВАННЯ БІОПЛІВКИ В БІОЕЛЕКТРОХІМІЧНИХ СИСТЕМАХ ПРИ ПЕРІОДИЧНОМУ РЕЖИМІ КУЛЬТИВУВАННЯ}

Анотація. У статті приведено короткий огляд методу формування анодної біоплівки з високою екзоелектрогенною активністю, який включає почергові повну $і$ часткову заміну поживного середовища. Проаналізовано вплив процесу адаптації на генерування електричного струму під час формування біоплівки. Пояснено причини різкого варіювання сили струму відразу після заміни поживного середовища.

Ключові слова: мікробні паливні елементи, екзоелектрогени, анодна біоплівка, очищення стічних вод. 